\title{
Retirement migration in Spain: two cases studies in Catalonian and Mallorca
}

\begin{abstract}
This paper presents part of the results of a wide-ranging qualitative investigation about the immigration of European citizens to Spain, entitled "European immigration: reverse discrimination?" And carried out by the Group for the Study of Immigration and Ethnic Minorities of the Autonomous University of Barcelona under the direction of Professor Carlota Solé. This research was carried out in the period 2002-2005 thanks to the funding received by the Research and Development (R \& D) program of the Ministry of Science and Technology.

Within the research of the European migratory flows, its relevant to study from a sociological perspective, the impact that the immigration of foreign retirees exercised in the Spanish municipalities of residence. In concrete in the creation of specific services for the elderly (day centers, places of residence, Home Care Services, Telecare, health services). Also, factors related to the life conditions and specific problems of retired immigrants must be considered. This brief paper presents some of the main results of a qualitative investigation that was pioneering in Spain and carried out between the years 2002-200.1

Related with the causes for emigrate, the research identified at less four immigrant profiles. Being specially interesting the retired people who emigrate for dependence assistance in Spain. Other relevant point is the evidences of the fragile social situations because dependences and loneliness. Especially hard in foreign old people whom haven't family networks due to migration. By other hand, the settle of retired foreign people in Spanish localities makes that the demand for social and health services grow up. The most of part of this demand is for private services that offer assistance in foreign languages as English, German o French. Actually, this can generate a special market for foreign old people who choose Spain not only for the weather but for the low prices of this kind of services.
\end{abstract}

Keywords: retirement migration, european union, european migration, social protection, social and health services, islas baleares, cataluña, españa
Volume 3 Issue I - 2018

\author{
Rosalina Alcalde Campos \\ tamento de Sociología, Universidad Autónoma de Barcelona, \\ Spain
}

Correspondence: Rosalina Alcalde Campos, Departamento de Sociología, Universidad Autónoma de Barcelona, Spain, Tel 3460034589, Email Rosalina.Alcalde@uab.cat

Received: December 05, 2017 | Published: January 03, 2018

\section{Introduction}

Currently in Spain there are 194,612 people older than 65 years coming from EU-27 countries: $43 \%$ are British citizens, $14 \%$ German citizens; 7.6\% French and 7.5\% Italian (National Institute of Statistics). At the beginning of 90 's it had been usually assumed that this group wasn't t very problematic in terms of social integration. ${ }^{1,2}$ However, our research revealed that there are different profiles of retired European immigrants that settle on Spanish coasts. What gives rise to very varied profiles and the generation of demand for specific services.

At the moment we did our research about European retirement migration in Spain in 2003, this topic was a phenomenon rarely studied by the sociology of migration in our country. ${ }^{3-5}$ Although this immigration flows were very significant in Spain. In this sense, we can say that our research was pretty pioneer in that research field in Spain. However, at the international level there were already researches such King Warnes \& Williams ${ }^{6}$ Willimas \& Hall ${ }^{7}$ and others referenced by Casado. $^{4}$

Nowadays we can find several works in Spain as Rafael Durán Muñoz's ${ }^{8}$ or in special, Mayte Echezarreta's line research ${ }^{9}$ about geronto immigration. In fact, Mayte Ecehzarreta has contributed with this concept to this research field and she conducts the Observatories
European de Geronto migrations in Malaga University. There is not doubt that Spain is a privileged place to study this migration.

The Spanish Mediterranean coast has been presented as the most attractive destination for community immigration. The flow of retired immigrants in Spain goes back to the sixties, marking the beginning of a foreign immigration that, until that moment, had been practically null. From the date until the mid-1980s, retired community foreigners have represented an important part of the growth of the resident foreign population. In particular, during the first half of that 90's decade, the coasts of the Balearic Islands, the Canary Islands and the Mediterranean became concentrations of homogeneous groups of retired and retired Europeans. Since the end of the eighties the flow of these immigrants has remained stable with the Valencian Community, Andalusia and the Balearic Islands as the communities with the largest number of this type of residents. ${ }^{1}$ The case of Catalonia, more specifically, the Costa Dorada (Tarragona), is also presented as an attractive destination, although the volume of this immigration is lower than on the island of Mallorca.

When our research team raised the study of foreign retirees in Spain, the initial hypotheses of investigation were two. The first one referred to whether the presence of concentration of community inactive in certain coastal areas of Catalonia and the Balearic Islands is leading to a localized increase in the demand for social services for 
older people with some degree of dependency. Similarly, we wonder if these new demands will simply an increase in jobs in these sectors covered mainly by community personnel. The second hypothesis that we tried to validate was whether the arrival of community retirees would be increasing the number of non-profit associations and selfhelp groups formed by their own compatriots in order to cover the specific needs of this group not addressed by the Administration. Likewise, an increase in private proximity services that would cover these same needs could be expected.

For space reasons, I will focus this brief paper in three evidences:

i. The causes of migration of people over 65 years of European origin (EU-15) to Spain.

ii. The living conditions of European people over 65 who retired in Spain.

iii. The specific demands of this group in relation to social and health services.

\section{Results}

From de phenomenological paradigm and using the discourse analysis of focus groups and interviews it can be summarized the next main results:

\section{In relation to the causes of emigration}

The reasons for the emigration of these European citizens appear coincidentally in the different studies carried out on the subject, agreeing with the findings of our own research: the climate and the lower cost of housing and life. However, the field work has shown that there are different and innovative profiles of retired community foreigners living in Cambrils and Calviá and that, therefore, the reasons for emigration and the installation in these municipalities respond, in certain cases, to other factors more related to old age and dependence. Thus, we have been able to distinguish, at least, five groups or profiles depending on the causes to choose the Spanish coast as a place of residence (we don't consider tourist):

Four profiles of retired European immigrants were identified.

i. Retired people who had gone from being tourists to being residents, whose main reasons for emigrating were the improvement of the quality of life due to the climate, the social network and the lower cost of living. These are people who vacationed in these locations before retirement and decide to settle permanently in the municipality looking for a nice place to spend their last years. Among these cases, no one interviewed raised the possibility of returning to their country of origin. However, there are cases in which the residence is shared between Spain and the country of origin (seasonal residence), which can be explained by the frequency of flights that exist between the countries of origin and Spain and their low cost. This fact is especially visible in the case of the airlines that cover the Germany-Mallorca route.

ii. European workers who worked in Spain and retired in Spain.

iii. People retired in their country of origin and regrouped by their sons in Spain.

iv. Retired people who immigrated to Spain to enter a residence for old people, that uses to be cheaper than in origin countries. These are people who lived in their country of origin and, due to their dependence status, emigrated to Spain to enter a nursing home-more or less according to the decision of their children-or to live with them. In these cases, it was the children who made the decision to reunify their parents, either to have them closes and to give them support, either because private residences in Spain were cheaper than in countries like Germany or England. Another reason that according to our interviewees could explain this phenomenon, were the long waiting lists in the nursing homes of the countries of origin, especially in the German case. By way of conclusion, we would like to highlight that although the profiles of retired community immigrants vary according to the causes of emigration, two profiles clearly appear related to aging and the need for attention to dependence: retired regrouped and those who they emigrate to enter private residences.

\section{In relation to living conditions}

In general terms, most of the interviewees agreed that an attraction factor to settle in Spanish municipalities was the fact that the quality of life is higher in Spain than in their countries of origin, which did not only refer to the climate (although it is a variable that constantly appears related to well-being and health), but to other factors such as the tranquility of the areas where they usually lived, the contact with nature and the sea and relations of friendship and friendship. However, as the years of residence in Spain were happening, a number of factors appeared that influenced the deterioration of the quality of life of this group: factors related to the degenerative process of aging and factors related to conditioning structural problems, such as the fragile Spanish Welfare State, the worsening of economic conditions and the EU's mobility framework clothes. In this way, what initially reported quality ends up becoming the fourth age, in discomfort. The main factors detected were:

a. Factors related to aging: health problems, mobility and dependence.

b. Factors related to housing: isolated dwellings and poorly communicated with urban centers and medical services; isolated areas vulnerable to insecurity; housing that is not adapted to mobility problems.

c. Economic factors: according to the amount of retirement pensions - this depends on the social protection systems of each origin country - and cost of living in Spain, especially housing and costs derived from private health care.

d. Scarce development of public services for dependency care in Spain.

e. Problems to access to public services.

f. Absence of family support networks. This aspect is the most characteristic element of foreign retirees in comparison with Spanish retirement people.

On the other hand, all the profiles coincided in a substantial element for our research: the progressive need to use socio-health services related to aging. The structural factors that we considered determine the use of the dependency care services among the community retirees residing in Calvià and Cambrils were:

a. The limited development of social services for dependency care in Spain. 
b. The absence of recognition of the export of social rights between countries of the Union

c. The different social protection systems of the countries of origin: different benefits, different amounts in benefits, different forms of law generation.

d. The absence in Spain of family support networks.

\section{In relation to the demand for services}

Finally, it was found that when there is a high presence of this type of immigration in certain Spanish localities, the demand for health services was activated. On numerous occasions, these services were offered from the market sphere by con-national professionals: medical consultations, private clinics, medical insurance, residences, home help, others. In short, the immigration of retired people represented a relevant object of study in the field of migration and social policy. Especially in the countries of Southern Europe such as Spain, given the volume of flow in certain areas of the Valencian Community, Andalusia, Canary Islands, Catalonia and the Balearic Islands.

This type of immigration has particularities in terms of its integration processes and in relation to the needs of attention to people of the third and fourth age. But at the present, the offer of services to families with dependent elderly people is totally insufficient in Spain in general, and in the cases of Catalonia and the Balearic Islands in particular. In this way, as we noted in our fieldwork, the main problem was not access or recognition of the right among EU citizens to public social services, but the inadequacy of the municipal offer in Home Care services and residential places. In relation to residence in Spain, the private offer prevails in the provision of residential services for the elderly. The same happened in the municipalities where the fieldwork was carried out. In Spain, private offer prevails in the provision of residential services for the elderly. The same happens in the municipalities where the fieldwork was carried out. A differential fact was detected between indigenous and community groups in the use of the residential service: while Spaniards mostly went to the public offer, foreign retirees did so to the private one. Among other factors, attention in their native languages was an incentive to attend this type of offer. In the cases studied, the sociosanitary staff was either originally from the countries of the residents, or they spoke languages. ${ }^{10-17}$

\section{Conclusion}

Immigration of inactive people from European Union countries not only activates employment within the service sector, particularly those related to social and health services, but in many cases the new positions are occupied by community workers. Mainly, this increase occurs from the commercial sphere, in some cases from the informal market (as was the case with personal attention services at home): consultations and private medical clinics, medical insurance, nursing homes, helpdesks at home and telecare. The demand for care for the elderly for foreigners is in their mother tongues, which gives foreign workers a certain "advantage" over native people. But the market of social health services for the foreign population is also interesting for Spanish companies, which require their staff linguistic competence, especially in English and German. The need to master the language of the users-clients is particularly necessary to make the offer of these personal services attractive.

On the other hand, the development of the private offer of personal services must be understood from the framework of analysis of the
Spanish welfare model. From the analysis of the state sphere, the scarce development of public policies aimed at the care of dependents, is a characteristic of our welfare model, which causes that the offer in services of attention is assumed by the market and from the quasimarkets generated from public entities. Or for families, that there are absent in the retired immigrants. The main effects of this privatization dynamic causes, first, the generation of inequalities by social class in the access and use of services. European retirees with high incomes resort to the private offer to obtain services that in many cases are non-existent or that are unsatisfactory in Spain. In the case of health care, complementarity between public and private services is also quite common. A second effect is the lack of supply of those services that may be unprofitable. Given the circumstances, the third sector performs an essential task, since they tend to a lesser selection of risks and assume the coverage of groups of complex attention and dispersed in the territory.

Nowadays we unknown how the impact of economic crisis in Spain could been affecting the life conditions of this collective. By other hand, the new Brexit context will have evident consequences in a part of British retirement people who live in Southern Europe. It will be necessary to continuing investigating in this field.

\section{Acknowledgements}

Research and Development (R \& D) program of the Ministry of Science and Technology, Spain.

\section{Conflict of interest}

The authors have no conflict of interest.

\section{References}

1. Ribera DA, Jamos A. La cuarta edad europea: envejecer en la costa Blanca. Madrid: Fundación Caja Madrid, Spain; 1993.

2. Salvà $\mathrm{P}$. La inmigración en Baleares: de un fenómeno tipo "nueva Florida" a un modelo migratorio de "nueva California, USA; 2003.

3. Alcalde R, Lurbe K, Moreno R. La inmigración de jubilados extranjeros en las costas mallorquinas y catalanas. Condiciones de vida $y$ utilización de los servicios sociosaitarios de atención a la dependencia. Nuevas fuentes de empleo. In: Solé C, editor. Migración comunitaria: discriminación inversa? Barcelona, Anthropos. 2006. p. 39-87.

4. Casado Díaz $\mathrm{M}^{\mathrm{a}} \mathrm{A}$. De turistas a residentes: inmigrantes retirados europeos en Torre Vieja, Costa Blanca. II Congreso Internacional sobre la inmigración en España: España y las migraciones internacionales en el cambio de siglo, Spain; 2000.

5. Durán Muños R. Atractivo de España para los jubilados europeos: del turismo a la gerontoinmigraciónImagen y presencia exterior de España. Spain; 2003.

6. Warnes A. Older migrants in Europe. She eld: She eld Institute for Studies, Ageing. 2004;32(8):1257-1281.

7. Williams AM, Hall M. Tourism and migration: New relationships between production and consumption. Tourism Geographies. 2000;2(1):5-27.

8. Duran R. Defining and Coping with Residence International Reteriment Migration to Spain. RIPSS. 2015;14(1):9-26.

9. Echezarreta MM. (coord.) La residencia de los gerontoinmigrantes. Derechos y obligaciones de los jubilados extranjeros en los lugares europeos de retiro: Valencia, Tirant lo Blanch, Spain; 2016.

10. Durán MA. Los costes invisibles de la enfermedad. Fundación BBVA, Bilbao, Spain; 2002. 
11. Esping AG. Los tres mundos del estado del bienestar. In: Diputació DV editor. Alfons el Magnánim, Italy; 1990.

12. King R, Warnes A, Williams AM. Sunset lives: British retirement migration to the Mediterranean. Oxford, Berg, UK; 2000.

13. International retirement migration in Europe. International Journal of Population Geography. 1998;4:91-111.

14. López de LD. A fines del siglo XX. Los que vienen a trabajar y los que vienen a descansar. Reis,Núm. 1995;71-72(95):225-245.
15. Sánchez M. Emigrar en la vejez. Tesis Doctoral. Universidad Complutense de Madrid, Spain; 1994.

16. Solé C. Inmigración comunitaria: discriminación inversa? Barcelona: Anthropos, Spain; 2006.

17. Geographical perspectives on the elderly. John Wiley and Sons, Chichester, UK; 1982. 